\title{
Effects of Weight Changes Produced by Exercise, Food Restriction, or Overeating on Body Composition
}

\author{
Lawrence B. Oscai and John O. Holloszy \\ From the Department of Preventive Medicine, Washington University School \\ of Medicine, St. Louis, Missouri 63110
}

A B S T R A C T The body weight of rats was reduced by exercise or by restriction of food intake over a period of $18 \mathrm{wk}$. Body composition was studied to determine if exercise protects against the loss of lean tissue that can occur as a result of a negative caloric balance.

Rats weighing $706 \pm 14 \mathrm{~g}$ were divided into four groups matched for weight. A baseline group was killed at the beginning of the study. An exercising group, fed ad lib., was subjected to a program of swimming. A sedentary, free-eating group was provided with food ad lib. Two sedentary, paired-weight subgroups were calorie restricted so that they lost weight at the same rate as the exercisers. The protein intake of one pairedweight subgroup was matched with that of the exercising group. The other sedentary, paired-weight animals ate the standard diet.

There was no significant difference in body composition between the two sedentary, paired-weight subgroups which were, therefore, pooled for comparison with the other groups. The exercisers lost $182 \pm 19 \mathrm{~g}$ as a result of both an increase in caloric expenditure and a decrease in appetite. The sedentary, food-restricted animals lost an average of $182 \pm 18 \mathrm{~g}$. The sedentary, freeeating animals gained $118 \pm 13 \mathrm{~g}$. The carcasses of the exercised animals contained significantly less fat and more lean tissue than those of the sedentary, pairedweight animals, providing evidence for a fat mobilizing and protein conserving effect of exercise. The composition of the body substance lost by the exercising animals was $78 \%$ fat, $5 \%$ protein, $1 \%$ minerals, and $16 \%$ water, compared to $62 \%$ fat, $11 \%$ protein, $1 \%$ minerals, and $26 \%$ water for the sedentary, food-restricted rats. Fat accounted for $87 \%$ and water for $10 \%$ of the weight gained by the sedentary, free-eating animals.

Dr. Oscai is a Postdoctoral Trainee in nutrition supported by Training Grant AM05341 from the U. S. Public Health Service.

Received for publication 2 June 1969 and in revised form 18 July 1969.

\section{INTRODUCTION}

Evidence has accumulated indicating that lean tissue, in addition to fat, is lost when the weight of an obese individual is reduced by means of calorie restriction (1-5). Estimates of the magnitude of this loss have varied considerably, possibly due to differences in methodology and to variation in individual responses to negative caloric balance. Keys and Brozek (1) and Brozek, Grande, Anderson, and Keys (4), on the basis of data obtained on 10 obese men who lost weight on a daily intake of $900 \mathrm{cal}$, calculated that fat-free weight accounted for $35 \%$ of the weight loss. In other reports, estimates of the lean component of the tissue lost in response to caloric restriction have varied from approximately 15 to $45 \%(2,3,5)$.

Studies on humans have provided evidence that individuals who exercise regularly have a greater lean body mass than sedentary individuals of the same weight (6). Similarly, in studies on growing rats, animals which exercised regularly were found to be leaner than sedentary animals that had their food intake restricted so that they gained weight at the same rate as the exercisers $(7,8)$. These observations suggested the possibility that exercise might protect against the loss of lean tissue that can occur when an individual is in negative caloric balance.

In the present study, the effects on body composition of weight reduction brought about by exercise alone and by caloric restriction alone were compared in obese rats. Information was also obtained regarding the changes in body composition that occurred in a comparable group of obese animals which continued to gain weight while remaining sedentary on an unrestricted diet.

\section{METHODS}

Animals, diet, and exercise program. 6 wk old rats of a Wistar strain (specific pathogen-free CFN rats) were obtained from Carworth Farms, kept in individual cages, and provided with food and water ad lib.

2124 The Journal of Clinical Investigation Volume $48 \quad 1969$ 
TABLE I

Body Composition of the Sedentary, Paired-Weight Subgroups

\begin{tabular}{lccccc}
\hline & & \multicolumn{3}{c}{ Body constituent } \\
\cline { 4 - 6 } \multicolumn{1}{c}{ Diet group } & Body weight* & Protein & Fat & Ash \\
\hline & $g$ & & & $\%$ & \\
Standard & $504 \pm 24$ & $14.5 \pm 0.7$ & $26.5 \pm 2.3$ & $2.5 \pm 0.2$ & $56.4 \pm 2.0$ \\
Supplemented $\ddagger$ & $496 \pm 27$ & $15.1 \pm 0.3$ & $26.6 \pm 2.4$ & $2.5 \pm 0.2$ & $55.9 \pm 2.1$ \\
\hline
\end{tabular}

Values are expressed as means \pm SEM. There were five animals in each group.

* After removal of hair and feces.

¥ Protein content was increased by substitution for sucrose in the standard diet, to equal the protein intake, for the previous week, of the exercising animals with which they were paired.

Their diet contained, in terms of per cent of total weight, casein $18 \%$, sucrose $49.25 \%$, corn oil $5.75 \%$, lard $17.25 \%$, brewer's yeast $2 \%$, liver powder $2 \%$, Hegsted salt mixture $4 \%$, vitamin fortification mixture $1.5 \%$, and cholesterol $0.25 \%$. This diet will be referred to as the "standard diet."

After 10 months, when they had attained an average weight of $706 \pm 14 \mathrm{~g}$, the animals were divided into four groups closely matched for weight.

A baseline group of seven animals was sacrificed immediately. An exercising group of 10 animals was subjected to a program of swimming over a period of $18 \mathrm{wk}$. They swam, in groups of three or four, in steel barrels with an internal diameter of $47 \mathrm{~cm}$ and a depth of $64 \mathrm{~cm}$. Water temperature was maintained between $32^{\circ}$ and $35^{\circ} \mathrm{C}$. During the first $6 \mathrm{wk}$, the animals swam 5 days per wk; the duration of the exercise sessions was progressively increased from 10 to $120 \mathrm{~min}$. For the next $4 \mathrm{wk}$ they swam for 120 min daily, 5 times per wk. The work was then further increased by attaching weights, equal to $1 \%$ of their body weights, to the animals' tails, and raising the frequency of the exercise sessions to 6 per wk. They were maintained at this work level for the last 8 wk of the study. The exercising animals were provided with food ad lib.

A sedentary, paired-weight group of 10 animals had their food intake restricted so as to result in a rate of weight loss comparable to that of the exercisers. As a result, the protein intake of the sedentary, food-restricted animals eating the standard diet was considerably lower than that of the exercisers. It has been shown that protein restriction, if it is sufficiently severe, can have a marked effect on lean body mass (8). It appeared likely, therefore, that, if any differences were found between the exercising and the pairedweight animals with respect to lean body mass, it would not be clear whether they were due to the exercise or to the difference in protein intake. In order to avoid this eventuality, the additional variable of protein intake was controlled by subdividing the paired-weight group into two matched subgroups. One subgroup ate the standard diet. The second subgroup ate a protein supplemented diet in which the protein content was increased (by substitution for sucrose) to equal the protein intake, for the previous week, of the exercising animals with which they were paired.

Two exercisers drowned before completion of the study. As a result, comparisons of the exercising and paired-weight control groups are based on the data obtained on the remaining eight exercisers and the eight food-restricted animals paired with them.

The fourth group contained seven sedentary free-eating animals that were provided with food and water ad lib.
Neither of the sedentary groups was subjected to any swimming.

The food intake of each animal was measured daily.

Carcass analysis. Rats were killed with ether after a terminal fast of $24 \mathrm{hr}$ duration. Hair was removed as described previously (8). Analyses were performed on the carcasses, from which the feces had been removed, by a modification (8) of the method of Mickelsen and Anderson (9).

Statistical methods. The significance of differences between the four groups have been determined, when appropriate, by either the $t$ test for the difference between the means or the $t$ test for paired observations (10).

Terminology. The terms fat-free weight and lean body mass are used synonymously in the following sections. They are defined as the weight of the whole carcass minus feces, hair, and total body fat.

Materials. Casein, Hegsted salt mixture, brewer's yeast, liver powder, and GBI vitamin fortification mixture were obtained from General Biochemicals Div., American Mogul Products Co., Chagrin Falls, Ohio.

\section{RESULTS}

Effect of protein supplementation on the body composition of the food-restricted animals. Protein intake for the protein-supplemented, paired-weight animals averaged $18.0 \pm 0.5 \mathrm{~g} / \mathrm{wk}$, compared with $18.0 \pm 0.4 \mathrm{~g}$ for the exercisers, and $13.0 \pm 0.5 \mathrm{~g}$ for the paired-weight controls on the standard diet. As shown in Table I, there was no significant difference in body composition between the paired-weight animals on the protein-

TABLE II

Caloric Intakes over an $18 \mathrm{Wk}$ Period

\begin{tabular}{lcccc}
\hline $\begin{array}{l}\text { Sedentary, } \\
\text { free-eating } \\
\text { rats. (7) }\end{array}$ & $\begin{array}{c}\text { Exercising } \\
\text { rats, (8) }\end{array}$ & Difference & $\begin{array}{c}\text { Sedentary, } \\
\text { paired-weight } \\
\text { rats, (8) }\end{array}$ & Difference \\
\hline \multicolumn{5}{c}{ calories } \\
$9985 \pm 342$ & $8935 \pm 147 \quad 1050^{*}$ & $6315 \pm 36$ & $2620 \ddagger$
\end{tabular}

Values are means \pm SEM. The number of animals per group is given in parentheses.

* Sedentary free-eating minus exercising, $P<0.02$.

$\ddagger$ Exercising minus sedentary paired-weight, $P<0.001$. 
TABLE III

Body Composition of the Four Groups

\begin{tabular}{lcccccc}
\hline \multicolumn{1}{c}{ Group } & Carcass weight* & Protein & Fat & Ash & Water \\
\hline & $g$ & & & $\%$ & & \\
Exercising (8) & $496 \pm 23$ & $17.0 \pm 0.4$ & $20.6 \pm 1.9$ & $2.5 \pm 0.20$ & $60.0 \pm 1.5$ \\
Sedentary, paired-weight (8) & $498 \pm 20$ & $14.7 \pm 0.3$ & $26.7 \pm 2.0$ & $2.5 \pm 0.01$ & $56.2 \pm 1.7$ \\
Sedentary, free-eaters (7) & $795 \pm 32$ & $12.3 \pm 0.2$ & $43.5 \pm 2.0$ & $1.7 \pm 0.01$ & $42.6 \pm 1.4$ \\
Baseline (7) & $676 \pm 39$ & $14.0 \pm 0.7$ & $35.6 \pm 2.6$ & $2.1 \pm 0.10$ & $48.5 \pm 1.9$ \\
\hline
\end{tabular}

Values are means \pm SEM. The number of animals per group is given in parentheses.

* After removal of hair and feces.

supplemented diet and those eating the standard diet. This finding indicates that the protein intake of the food-restricted animals on the standard diet was no: decreased sufficiently to exert an independent effect on lean body mass. The two paired-weight groups have, therefore, been pooled and will be referred to jointly as the "paired-weight" or "food-restricted" animals.

Caloric balance and body weight. The exercise program resulted in a chronically negative caloric balance, reflected in an average weight loss of $182 \pm 19 \mathrm{~g}$. This was due to both a decrease in appetite, as evidenced by a voluntary food intake that was significantly lower than that of the sedentary, free-eating animals, and an increased caloric expenditure (Table II). The latter averaged approximately $2847 \mathrm{cal}$ per rat over the $18 \mathrm{wk}$ period. This value was obtained by adding the difference between the caloric contents of the carcasses of the sedentary, paired-weight animals and the exercisers to the differences between the caloric intakes of these two groups.

The weight loss of the sedentary, food-restricted animals closely paralleled that of the exercisers, averaging 182 $\pm 18 \mathrm{~g}$ for the $18 \mathrm{wk}$ period. The sedentary, free-eating animals remained in positive caloric balance throughout the study, gaining an additional $118 \pm 13 \mathrm{~g}$.

Effects of exercise on body composition. The major portion $(78 \%)$ of the weight loss that occurred in the exercising animals was due to the loss of fat (Tables III, IV, and V). At the end of the study, the body fat content of the exercisers was less than one-half of that of the baseline group $(P<0.001)$ and less than one-third of that of the free-eating, sedentary animals $(P<0.001)$ (Table IV). As a result, significant increases occurred in the proportions of the body composed of protein $(P<$ $0.01)$ and of water $(P<0.001)$ (Table III). However, the total amounts of protein, ash, and water contained in the carcasses of the exercising animals were decreased slightly compared with those of the baseline group ( Table IV). So, although their relative lean body mass was increased $(79.5 \pm 1.8 \%$ vs. $64.6 \pm 2.5 \% ; P<0.001)$, the total lean body mass of the exercising animals was, on the average, smaller than that of the baseline group ( $391 \pm 10 \mathrm{~g}$ vs. $431 \pm 16 \mathrm{~g} ; P<0.05$ ) (Tables III and IV).

Effects of caloric restriction on body composition. As shown in Table V, 38\% of the weight loss that occurred in the food-restricted animals consisted of lean tissue and $62 \%$ of fat. The proportion of fat decreased $(P<$ $0.02)$, and the proportion of lean tissue increased $(P<$ 0.01 ) (Table III). Total lean body mass was significantly decreased $(P<0.01)$ due to decreases in both total body protein $(P<0.001)$ and water $(P<0.01)$ (Table IV).

Comparison of exercised and food-restricted animals. Although the total weight loss and final weights were essentially the same for the exercisers and the sedentary, paired-weight controls, their carcasses were significantly different in composition. The carcasses of the exercised animals contained less fat $(P<0.01)$ and more protein $(P<0.001)$ and water $(P<0.02)$ than those

TABLE IV

Total Body Content of Protein, Fat, Minerals, and Water of the Four Groups

\begin{tabular}{lccccc}
\hline \multicolumn{1}{c}{ Group } & Carcass weight* & Protein & Fat & Ash & Water \\
\hline & $\mathrm{g}$ & & & & \\
Exercising (8) & $496 \pm 23$ & $84.2 \pm 3.5$ & $105.2 \pm 14.6$ & $12.2 \pm 0.7$ & $295.2 \pm 7.0$ \\
Sedentary, paired-weight (8) & $498 \pm 20$ & $73.0 \pm 2.7$ & $135.4 \pm 14.9$ & $12.3 \pm 0.1$ & $278.1 \pm 5.8$ \\
Sedentary, free-eaters (7) & $795 \pm 32$ & $96.3 \pm 2.3$ & $349.1 \pm 29.2$ & $13.7 \pm 0.3$ & $337.0 \pm 8.6$ \\
Baseline (7) & $676 \pm 39$ & $93.0 \pm 2.4$ & $245.0 \pm 30.4$ & $13.9 \pm 0.6$ & $324.8 \pm 14.5$ \\
\hline
\end{tabular}

Values are means \pm SEM. The number of animals per group is given in parentheses.

* After removal of hair and feces. 
of the sedentary, food-restricted controls (Table III and IV).

The total amount of protein lost during the period of weight reduction was more than twice as great for the sedentary, food-restricted rats as for the exercised animals (Table IV and V).

Effect of weight gain on body composition of the sedentary, free-eating animals. As shown in Table V, almost all of the weight gain that occurred in the sedentary, free-eating animals was due to an increase in fat. As a result of the increase in body fat content $(P<$ 0.05 ) (Tables III and IV) the relative proportions of water and of minerals decreased significantly $(P<0.05)$ (Table III). However, total carcass protein, minerals, and water were not significantly altered (Table IV).

Composition of the fat-free carcasses. Although the composition of the whole body differed markedly among the four groups (Tables III and IV), the proportions of protein, minerals, and water in their fat-free carcasses were essentially the same (Table VI). Thus, over a wide range, the composition of the lean body mass appears to remain constant regardless of body fat content.

\section{DISCUSSION}

The exercise program resulted in a gradual weight loss over the $18 \mathrm{wk}$ period of the study. This weight loss, which amounted to approximately $25 \%$ of the animals' initial weight, resulted from both a suppression of appetite and an increase in calorie expenditure, with the latter contributing roughly three times as much as the former to the negative energy balance. It has, in the past, been noted that rats exercised by swimming often develop pulmonary infections. We have not had this problem with our pathogen-free animals. In the present study, the lungs of the animals were inspected, and appeared normal. Further evidence that the animals were healthy and losing weight only as a result of the exer-

TABLE V

Composition of the Tissue Lost or Gained*

\begin{tabular}{cccccc}
\hline Group & $\begin{array}{c}\text { Direction of } \\
\text { change }\end{array}$ & Protein & Fat & Ash & Water \\
\hline $\begin{array}{l}\text { Exercising (8) } \\
\begin{array}{c}\text { Sedentary, paired } \\
\text { weight (8) }\end{array}\end{array}$ & Decrease & 5 & 78 & 1 & 16 \\
$\begin{array}{c}\text { Sedentary, free- } \\
\text { eating (7) }\end{array}$ & Decrease & 11 & 62 & 1 & 26 \\
\hline
\end{tabular}

The number of animals per group is given in parentheses.

* In calculating the composition of the weight loss and weight gain tissues, the assumption was made that the body composition was the same for the three experimental groups and the baseline group at the beginning of the study.
TABLE VI

Composition of the Fat-Free Carcasses of the Four Groups

\begin{tabular}{|c|c|c|c|c|}
\hline Group & $\begin{array}{l}\text { Fat-free } \\
\text { weight }\end{array}$ & Protein & Ash & Water \\
\hline & $g$ & & $\%$ & \\
\hline Exercising (8) & $391 \pm 10$ & 21.5 & 3.1 & 75.4 \\
\hline $\begin{array}{l}\text { Sedentary, paired- } \\
\text { weight ( } 8)\end{array}$ & $363 \pm 8$ & 20.1 & 3.3 & 76.6 \\
\hline $\begin{array}{l}\text { Szdentary, free- } \\
\text { eaters }(7)\end{array}$ & $446 \pm 9$ & 21.5 & 3.1 & 75.4 \\
\hline Baseline (7) & $431 \pm 16$ & 21.5 & 3.2 & 75.2 \\
\hline
\end{tabular}

The number of animals per group is given in parentheses.

cise program is provided by the finding that they gained weight rapidly on the days on which they were not exercised.

The finding that prolonged, vigorous exercise results in a voluntary decrease of food intake in rats is in keeping with earlier studies by Stevenson, Box, Feleki, and Beaton (11), and in this laboratory (8). It is our working hypothesis (8) that the appetite suppression may be mediated by the increased levels of catecholamines associated with the stress of exercise $(12,13)$.

The exercise provided significant, but not complete, protection against the loss of protein and fat-free weight associated with a negative caloric balance. Although the weight loss of the exercising and the sedentary, calorierestricted animals was the same, the exercisers lost significantly more fat and less than one-half as much protein. The finding that the exercising animals were leaner than the sedentary controls of the same weight, points to a lipid-mobilizing effect of exercise, in addition to the increase in calorie expenditure and the decrease in food intake. It has been shown that during prolonged exercise, fatty acid mobilization does increase markedly (14-16). This effect appears to be mediated, in part, by increased activity of the sympathetic nervous system $(12,17)$. It appears possible that the cumulative effects of daily, exercise-induced bouts of lipolysis could be responsible for the greater fat loss of the exercised animals. Furthermore, this fat-mobilizing effect, which persists for a considerable time after the cessation of exercise $(15,16)$, could play a role in the conservation of lean tissue by making available to muscle and organ cells more of the energy stored as fat. The greater lean body mass of the exercising animals, as compared with the sedentary, food-restricted controls, could also reflect stimuli for amino acid conservation and protein synthesis, such as a direct effect of exercise on muscle (18) and the anabolic effects of increased levels of growth hormone secretion secondary to the exercise (19).

It is of interest that the composition of the tissue lost 
by the sedentary, paired-weight animals in the present study $(62 \%$ fat) is almost identical with that calculated by Brozek et al. (4) for 10 obese men whose caloric intake was restricted for $10 \mathrm{wk}(64 \%$ fat $)$, and by Young and Di Giacomo (5), using the formula of Entenman, Goldwater, Ayres, and Behnke (2), on eight obese subjects who were on a restricted food intake for $12 \mathrm{wk}(61 \%)$.

In a study in which a group of initially underweight men increased their weights by overeating, Keys, Anderson, and Brozek (20) calculated that the tissue gained was approximately $62 \%$ fat. In contrast, in the present study the weight gain tissue of the sedentary obese rats that were permitted unrestricted access to food was $87 \%$ fat. This difference appears to be related to the initial state of nutrition; apparently the more obese an animal the smaller is the lean component of any further weight gain $^{1}$ (21). In rats gaining weight from approximately $500 \mathrm{~g}$ to $700 \mathrm{~g}$, fat was responsible for approximately $58 \%$ of the weight gain $;^{1}$ this value is quite similar to that found by Keys et al. in their human subjects who overate (20), and closely resembles that found for the weight loss tissue of the sedentary, paired-weight animals in the present study $(62 \%)$.

The results of this study demonstrate that in obese rats, as in obese humans, one-third or more of the weight lost as a result of caloric restriction may be accounted for by loss of lean tissue. They also show that a comparable reduction of weight induced by means of exercise is associated with the loss of significantly less lean tissue and significantly more fat. This finding may be of some clinical interest when viewed in the context of studies showing that prolonged exercise can, under some circumstances, be effectively incorporated into weight-reducing programs for obese patients $(22,23)$.

\section{ACKNOWLEDGMENTS}

We wish to express our appreciation to Mr. Wayne Sauey for skillful technical assistance, and to Mrs. Lenore Alberty for assistance in the preparation of this manuscript.

This work was supported by U. S. Public Health Service Research Grant HDO1613 from the National Institute of Child Health and Human Development, and by Training Grant AMO5341 from the National Institute of Arthritis and Metabolic Diseases. J. O. Holloszy is the recipient of U. S. Public Health Service Research Career Development Award K4-HD-19,573.

\section{REFERENCES}

1. Keys, A., and J. Brozek. 1953. Body fat in adult man. Physiol. Rev. 33: 245.

2. Entenman, C., W. H. Goldwater, N. S. Ayres, and A. R. Behnke, Jr. 1958. Analysis of adipose tissue in relation to body weight loss in man. J. Appl. Physiol. 13: 129.

3. Ljunggren, H., D. Ikkos, and R. Luft. 1959. The com-

\footnotetext{
${ }^{1}$ Oscai, L. B., and J. O. Holloszy. Unpublished observation.
}

position of tissue lost through reduction of diet in obese patients. Brit. J. Nutr. 13: 485.

4. Brozek, J., F. Grande, J. T. Anderson, and A. Keys. 1963. Densitometric analysis of body composition: revision of some quantitative assumptions. Ann. N. $Y$. Acad. Sci. 110: 113 .

5. Young, C. M., and M. M. Di Giacomo. 1965. Protein utilization and changes in body composition during weight reduction. Metabolism. 14: 1084.

6. Pařízková, J. 1963. Impact of age, diet, and exercise on man's body composition. Ann. N. Y. Acad. Sci. 110: 661 .

7. Jones, E. M., H. J. Montoye, P. B. Johnson, S. M. J. M. Martin, W. D. Van Huss, and D. Cederquist. 1964. Effects of exercise and food restriction on serum cholesterol and liver lipids. Amer. J. Physiol. 207: 460.

8. Crews, E. L., III, K. W. Fuge, L. B. Oscai, J. O. Holloszy, and R. E. Shank. 1969. Weight, food intake, and body composition: effects of exercise and of protein deficiency. Amer. J. Physiol. 216: 359.

9. Mickelsen, O., and A. A. Anderson. 1959. A method for preparing intact animals for carcass analyses. J. Lab. Clin. Med. 53: 282.

10. Edwards, A. L. 1963. Statistical Methods for the Behavioral Sciences. Holt, Rinehart \& Winston Inc., New York. 2nd edition. 278.

11. Stevenson, J. A. F., B. M. Box, V. Feleki, and J. R. Beaton. 1966. Bouts of exercise and food intake in the rat. J. Appl. Physiol. 21: 118.

12. Vendsalu, A. 1960. Plasma concentrations of adrenaline and noradrenaline during muscular work. Acta Physiol. Scand. Suppl. 173: 57.

13. Russek, M., and S. Piña. 1962. Conditioning of adrenalin anorexia. Nature (London). 193: 1296.

14. Basu, A., R. Passmore, and J. A. Strong. 1960. The effect of exercise on the level of non-esterified fatty acids in blood. Quart. J. Exp. Physiol. 45: 312.

15. Havel, R. J., A. Naimark, and C. F. Borchgrevink. 1963. Turnover rate and oxidation of free fatty acids of blood plasma in man during exercise: studies during continuous infusion of palmitate-1-C $\mathrm{C}^{14}$. J. Clin. Invest. 42: 1054.

16. Rodahl, K., H. I. Miller, and B. Issekutz, Jr. 1964. Plasma free fatty acids in exercise. J. Appl. Physiol. 19: 489.

17. Muir, G. G., D. A. Chamberlain, and D. T. Pedoe. 1964. Effects of $\beta$-sympathetic blockade on non-esterified-fattyacid and carbohydrate methabolism at rest and during exercise. Lancet. 2: 930.

18. Hamosh, M., M. Lesch, J. Baron, and S. Kaufman. 1967. Enhanced protein synthesis in a cell-free system from hypertrophied skeletal muscle. Science (Washington). $157: 935$

19. Glick, S. M., J. Roth, R. S. Yalow, and S. A. Berson. 1965. The regulation of growth hormone secretion. Recent Progr. Hormone Res. 21: 241.

20. Keys, A., J. T. Anderson, and J. Brozek. 1955. Weight gain from simple overeating. Metabolism. 4: 427.

21. Schemmel, R., O. Mickelsen, and Z. Tolgay. 1969. Dietary obesity in rats: influence of diet, weight, age and sex on body composition. Amer. J. Physiol. 216: 373.

22. Buskirk, E. R., R. H. Thompson, L. Lutwak, and G. D. Whedon. 1963. Energy balance of obese patients during weight reduction: influence of diet restriction and exercise. Ann. N. Y. Acad. Sci. 110: 918.

23. Strong, J. A., R. Passmore, and F. J. Ritchie. 1958. Clinical observations on obese patients during a strict reducing regimen. Brit. J. Nutr. 12: 105. 